\title{
Reviewing the Notions of Construction Project Success
}

\author{
Wai Soon Han (Corresponding author) \\ Faculty of Civil Engineering, University of Technology Malaysia \\ Skudai 81300, Johor Bahru, Malaysia
}

Tel: 60-12-214-0213 E-mail: shwai2@live.utm.my

Aminah Md. Yusof

Faculty of Civil Engineering, University of Technology Malaysia

Skudai 81300, Johor Bahru, Malaysia

Tel: 60-12-710-2340 E-mail: aminahyusof@utm.my

Syuhaida Ismail

Department of Civil Engineering, University of Technology Malaysia International Campus

Kuala Lumpur, Malaysia

Tel: 60-12-646-9235Ｅ-mail: syuhaida@ic.utm.my

$\mathrm{Ng}$ Choon Aun

Faculty of Engineering and Green Technology, University of Tunku Abdul Rahman

Kampar 31900, Perak, Malaysia

Tel: 60-17-668-0789Ｅ-mail: ngca@utar.edu.my

Received: July 17, 2011

doi:10.5539/ijbm.v7n1p90
Accepted: September 7, 2011

Published: January 1, 2012

The research is financed by Grant for Research University (GUP) of University of Technology Malaysia, Johor under Cost Centre No. Q.K130000.7140.00H47

\begin{abstract}
Defining project success is an elusive topic. The lack of an agreed definition for project success has long been the reason for failing to define and evaluate success. In fact, the matter of whether or not it is necessary to define success remains a huge doubt. The topic may become more complicated in the context of construction industry. The reasons are high inherent risk, one-of-a-kind end product and vulnerable to various uncertainties. As the construction project success expands rapidly, the need for identification of new research area increases simultaneously. This paper, therefore, provides a review of the project success notions and proposes a conceptual framework that identifies the relationship between success factors and criteria as a new research area in construction project success. This paper will help researcher to identify the most devoted notions of construction success and attract more researches to enhance the construction project success.
\end{abstract}

Keywords: Construction project success, Project success factor, Project success criteria, Literature review

\section{Introduction}

Construction industry, by and large, attracts most attention as compared to other industry (Bett \& Lansley, 1995; Pinto \& Slevin, 1988). Although the sector only represents a small percent of total number of projects executed (Evaristo \& van Fenema, 1999), the sector has an influencing bearing on project management practice (Crawford, Pollack \& England, 2006). Construction projects are naturally complex due to its wide divergence of project sites, 
high pressure on demanding construction time and cost as well as increasing complexity on construction techniques (HSE, 2001). It is therefore no agreed definition on construction project success. Definitions mean for achieving agreement and contribute towards a better understanding of differences (Pryke \& Smyth, 2006).

In this sense, the differences between project success and project management success are first discussed as follows. Project success is the assessment of overall objectives of the project, whilst project management success is the assessment of the traditional measures of performance against cost, time, and quality (De Wit, 1988). Project success deals with concerns for efficiency and effectiveness, either internally or external and short term or long term (Shenhar, Levy \& Dvir, 1997). Contrarily, project management success accounts only internal efficiency to the project team (Ika, 2009). One can conclude that project success deals with the broader aspect of a project. In fact, it is hardly overstated that project management success is one of the elements of project success because the latter is unattainable without the former.

Having discussed the differences between project success and project management success, Baker, Murphy \& Fisher (1988) suggest that there is no such thing as an absolute success in a project and there is only perceived success. This has also led to the prevailing example that says "architects usually place emphasis priority on aesthetic aspect of a building while the engineers usually focus on the structural aspect of a building" (Freeman $\&$ Beale, 1992). As such, construction project success requires broader research area as different people has different perspective on a similar issue. To achieve this, reviewing the notions of construction project success is necessary. It is the contention of this paper that there is a difference between project success and project performance. Semantically, project success is measurable only after the project is completed (Morris \& Hough, 1987), while project performance is measurable during the life of the project (Cooke-Davies, 2002) where the latter is beyond the focus of this paper.

This paper is structured as follows: in section 2, project success factors and project success criteria are briefly reviewed respectively; in section 3, research methodology of this paper is presented; in section 4, conceptual framework for construction project success is discussed; and in section 5, the summary and conclusion of this paper is made.

\section{Literature Review}

In a construction project context, research into project success generally falls into either one of the avenues that examine project success factors or deal with success criteria (Ika, 2009). Additionally, the emergence of project success factors and success criteria as a prerequisite to the study of project success is agreed upon across literature world (Ika, 2009). This forms the basis of literature review that is discussed in the following subsection.

\subsection{Project Success Factors}

Success factors are factors that influence, constitute as well as determine the success of a project. This definition is adapted in this paper. Rubin \& Seeling (1976) first introduce the concept of project success factors in 1976. Rockart (1982) first uses the terminology critical success factors (CSFs) and defines it as those few key factors absolutely necessary to reach goals. McCabe (2001) highlights CSFs are vital for managers to improve their organization in the sense that it will indicate the progress is being made in particular areas. Nevertheless, this paper assumes these terms are basically the same in terms of definitional aspect. Having this in mind, the previous work in this field will be reviewed in more details as described below.

The review begins with the search for project success factors that had been identified before 1990s. From the search, similarities exits among project success factors across literature namely definition of project objective and goal (Lock, 1984; Martin, 1976; Morris \& Hough, 1987) as well as general and top management support (Cleland \& King, 1983; Martin, 1976; Pinto \& Slevin, 1989). Although the knowledge (before 1990) in this area was far short from perfection, these studies, however, trigger the flourishing of research which is related to CSFs. One of the famous studies that differentiate project success and project management success (De Wit, 1988) is the work done within this period of time. Additionally, there is already a tendency to conduct research that would take into consideration the project life cycle (Pinto \& Slevin, 1988).

The $20^{\text {th }}$ century witnesses the growth of focus on project success factors. Among the findings are human factors such as communication, teamwork and leadership that affect the accomplishment of project objectives successfully (Verma, 1995 \& 1996). In subsequent research, King (1996) ponders exhaustive approach on success factors. The multi-faceted concept of project success factors may be the reason for the idea. Gidado (1996) agrees that project success is complex and there may be many other underlying dimensions. Consequently, Belassi \& Tukel (1996) categorise project success factors into factors related to the project, factors related to the 
project manager and team members, factors related to the organisation, and factors related to the external environment. The authors assume that the categorization process will capture sufficient factors, if not all. They have broadened the success factors coverage, but these groups of factors failed to link the factors to project lifecycle. In this sense, Wateridge (1995) suggests to select the CSFs at the outset of a project and clarify the success criteria accordingly so that all stakeholders appear to agree on it. The interest in project success factor was rising until there was assumption that project success factor should stand alone due to diversity of projects in environmental variables, the nature of participant's organisation, and the prioritisation of project goals (Belassi \& Tukel, 1996; Liu, 1999). In relation to this assumption, the concept of CFS may be applied to the project per se, the consortium that sponsors the project, and the political, social, and economic environments where the project is located in Build, Operate, and Transfer (BOT) projects (Tiong, Yeo \& McCarthy, 1992). In the same vein, within the building construction projects, Sanvido, Grobler, Parfitt, Guvenis \& Coyle (1992) suggest another four CSFs namely a comprehensive facility team, teamwork boosting policy, sufficient of experience in handling various aspects of facilities, and information optimisation in the planning and design stage. In addition, Chua, Kog \& Loh (1999) identify specific CSFs for different construction project objectives of budget, schedule and quality for appropriate allocation of limited resources. Since the budget, schedule and quality are naturally interrelated, the specific CSFs seems make sense in theory but not in practical. For example, project manager competency is needed for achieving the trio objectives but not for particular objective. Obviously, the state of knowledge in project success factor has gradually grown over the decade and contributed to the overall body of knowledge in this field.

In recent years, the context-driven research on project success factors has gradually gained interest. For example, the understandings of CSFs in project management within an organisational context have been presented (Hyvari, 2006). In addition, there are also researches conducted within the context of value management (Shen \& Liu, 2003), project sponsorship (Bryde, 2008), stakeholder management (Jing, Shen, Drew \& Ho, 2010), waste management (Lu \& Yuan, 2010), and sustainability housing (Abu Bakar, Abdul Razak \& Abdullah \& Awang, 2010). Table 1 shows the summary of success factors from these researches. Although context-driven research may differ on the nature of focus, there are some common factors such as clear objectives, strategies and project benefits that would have to take into consideration at the outset of any project. However, the implication of context-driven research is limited to the countries where the data have been collected, and hence, it would be better to have more researches to cater the nature and structure of the local construction industry. Having this in mind, four CSFs groupings namely comprehensive, competence, commitment, and communication are identified as critical in large-scale construction project in Thailand construction industry (Toor \& Ogunlana, 2008). Meanwhile, Nguyen, Ogunlana \& Lan (2004) perceive project success factors may be grouped into four COMs namely comfort, competence, commitment, and communication in large construction projects in Vietnam. Furthermore, a modeling of critical success factors is conducted which identifies strategic, project control, technical, commercial, organisation, and people as crucial in construction project management within South African construction industry (Chileshe \& Haupt, 2005).

\subsection{Project Success Criteria}

Having conferred the success factors alone, project success would not be perfect without the success criteria. Turner, (1999) suggests there is no point in determining success factors until one has identified the success criteria at the first place. In addition, the project success seems to be more complete with both project success factors and success criteria are taken into consideration as a whole (Ika, 2009). Within the context of construction industry, its complexity draws most attention into project success by looking at measuring and assessing project dependent on perceived criteria.

Most authors such as Al-Tmeemy et al. (2011); Atkinson (1999); Baccarini (1999); Belassi \& Tukel (1996); Hatush \& Skitmore (1997); Lim and Mohammad (1999) and Navarre \& Schaan (1990), regardless of time space, have postulated time, cost, and quality as a basic foundation in assessing the project success. Construction industry is a case in point given the trilogy will culminate in profit related concerns. However, questions and concerns are raised about the insufficiency in this trilogy per se as success criteria. Baccarini, (1999) suggests product success, which consists of owner's strategy, user satisfaction, profitability, and market share together with project management success, which resembles the time, cost, quality, project management process and stakeholders' satisfaction as components that form project success concept.

Lim \& Mohammad (1999) disperse success criteria into micro viewpoint completion (e.g. time, cost, quality, performance and safety) and macro viewpoint completion (e.g. time, satisfaction, utility, and operation). In the same vein, Chan \& Chan (2004) and Crawford \& Pollack (2004) group construction project success criteria into objective measures (e.g. time, cost, safety and environment) and subjective measures (e.g. quality, functionality 
and satisfaction of different project participants). Furthermore, Blindenbach-Driessen (2006) suggests a model that consists of project success (e.g. adherence to quality target, schedule, budget, and captured knowledge) and market success (e.g. profitability, revenue, market share, reputation competitive advantage and customer satisfaction). Al-Tmeemy et al. (2011) further combine project success, market success and product success to form future criteria for assessing success of building projects in Malaysia as portrayed in Figure 1. These researches ponder quantitative measures and qualitative measures. Since standard framework has yet to be documented, two groups of protagonists consequently exist. The first group has been prone to qualitative measurement (Munns \& Bjeirmi, 1996) because of the admiration to crisp value concept. Contrarily, the other group fancies quantitative measure. The debate seems no end simply because researches into success criteria tends to make assumption at first place, ceteris paribus, where the outcome only affected by criteria perceived to be prominent.

Given the widely accepted ambiguous, assessing success criteria based on project stages has emerged. Assessing project success is made on the altar of delivery stage and post delivery stage (Atkinson, 1999). The delivery stage is adherence to cost, time, quality, and efficiency. Meanwhile, there are benefits to stakeholders, criteria from project manager, top management, resultant system, impact on customer and business success found in post delivery stage. In the same vein, the project lifecycle of international development project are divided into five stages namely conceptualising, planning, implementing, closing, and overall project success (Do \& Tun, 2008). The authors further assign different success criteria to the project lifecycle stages as portrayed in Table 2. Chan, Scott \& Lam (2002) further divide the success criteria into objective and subjective measure under project lifecycles namely pre-construction stage, construction stage, and post-construction stage respectively. Similar to this avenue, Shenhar \& Renier, (1996) focus on success category namely internal project objectives, benefit to customer, direct contribution and future opportunity which resemble pre-completion, short term, medium term and long term respectively. The in-depth measurable success criteria are shown in Table 3 . The authors are pioneer in typologizing project success criteria. The basic assumption behind the scene is success varies with time. The research seems to be the robust as it takes into consideration the project success and project management success components as well. Additionally, Shenhar, Dvir, Levy \& Maltz (2001) claim that project success represents strategic management concept as all efforts must be in accordance with the strategic long-term goals of the organization. However, concerns are raised over the project classification across industry. As a result, construction is seen as a breakdown unit of an industry where different industries could have involved with construction projects. Nevertheless, the typological concept of project success remains doubt over application in construction projects.

Given the character of success criteria is inherently multidimensional, Shenhar et al. (1997) suggest four dimensions of project success criteria namely project efficiency, impact on customer, business success, and preparing for the future. At the mean time, Sadeh, Dvir \& Shenhar (2000) divide success dimension into meeting design goals, benefits to the end user, benefits to the developing organisation, and benefit to the defence and national infrastructure. In addition, Diallo \& Thuillier (2004) posit three empirical macro dimension namely management success, project itself and profile of international development project as shown in Table 4. These researches, however, tend to create simplicity out of the knowledge itself. This is the prevailing assumption concerning the validation process of exhaustive data. Moreover, the practically impact remains a doubt. It seems paradoxical, but that is the imperfection of the knowledge unless a robust validation method comes in sight.

Lastly, prevailing trend is noted in studying the project success criteria based on individually stakeholder's perspective. As the project success could be assessed by different stakeholders namely clients, managers, contractors, workers, and end-user, the relevant criteria, therefore, must represent different views (Stuckenbruck, 1986). Bryde \& Robinson (2005) show that client puts more emphasis on the need of other stakeholders whilst contractor puts more emphasis on project cost and duration. Being the main person in any project, the perspective of client has drawn more attention compared to other stakeholders. For example, Frodell (2008) depicts an empirical result that shows success measures like keeping project on time, within budget, maintenance costs and project goals as well as ensuring profitability are important criteria. At the meantime, Ellatar (2009) suggests a trilogy perspective framework on construction project. As suggested, client's perspective (e.g. time, cost, functionality, end result, quality, aesthetic value, profitability, marketability, less aggravation), designer's perspective (e.g. satisfied client, quality, cost and profit, professional related issues like staff fulfillment, marketable product, less construction problem, no liability, socially accepted, client pays and well defined scope of work) and contractor's perspective (e.g. time, cost, quality, free from claims, clearly defined expectation from all parties, client satisfaction, as well as less surprises during project) are prominent to increase the likelihood of project success. Generally, the perspective research has several limitations: first, it concerns about individually 
stakeholder's viewpoint and overlooks the interrelationship among stakeholders. Second, no universal accepted methods for measuring subjective measures and it only exacerbates the problem by putting objective and subjective measures together. Third and lastly, should it be more contexts specific to incorporate the type of project, procurement method, and within different country remains vague.

\section{Research Methodology}

The research method of this paper is mainly based on a literature review of construction project success notion. Although this paper places emphasis upon construction industry, the literature review, however will not only limited to the industry alone. A conceptual framework is first proposed primary based on literature review with two sub notions: project success factors and success criteria. The framework is then modified to identify the new research area. The details of the proposed conceptual framework are discussed in the following section.

\section{Conceptual Framework of Construction Project Success}

As mentioned in Section 2, project success factors and project success criteria are the most devoted notions of construction project success. A comprehensive review conducted in Section 2 echoes this finding. Based on this review, a conceptual framework can be first established as shown in Figure 2. This framework is modified to identify the new research area as shown in Figure 3. The intersection area represents the relationship between project success factors and project success criteria. In response to the intersection area, little research has emerged in literature. Cases in point include: empirical model formulated by Westerveld, (2003), regression model adapted by Anderson, Birchall, Jessen \& Money (2006), structural equation modeling employed by $\mathrm{Ng}$, Wong \& Wong, (2010). This current $\mathrm{PhD}$ research will follow these similar approaches by looking at the relationship between project success factors and project success criteria. Although this $\mathrm{PhD}$ research is still in its infancy stage, it is foreseeable that the structural equation modeling as employed by $\mathrm{Ng}$ et al., (2010) could be used to examine the relationships.

\section{Summary and Conclusion}

Project success is a vague concept. There is no exception in construction project success. In fact, the project success concept in the context of construction industry may be even more complicated as it involves plenty of stakeholders, possesses higher inherent risk and vulnerable to various external factors such as political and economic. Consequently, it is difficult to precisely define success of a construction project as some of the criteria are successfully met, while others are not. Identification of new research area that serves as one of the aim of this paper is a necessity.

This paper provides a conceptual framework for enhancing project success by identifying the relationship between success factors and success criteria as a research area that worth a look at. A literature review that summarized in Table 5 echoes this where only few researches are found in the area. It is important to note that identification of project success factors or project success criteria is an important step in capturing lesson learned. Lesson learned is usually documented to increase the success likelihood of future project. As the area relationship between project success factors and criteria stands under the project success domain, it possesses the same nature. In this sense, it would be ideal if the relationship between success factors and criteria is examined within the same type of construction project.

The conceptual framework documented in this paper is a topic of ongoing research at University of Technology Malaysia towards an award of a doctoral degree. This paper provides direction for the PhD research, where an investigation of relationship between construction project success factors and criteria is needed as it has been attracted less attention across the literature. The overall objective of the investigation is to establish a robust relationship framework that depicts the linkage between the success factors and criteria that could be of managerially useful, end-to-end view of the cause effect process from a construction perspective. Future research direction could be developing similar relationship framework for other projects in different industries based on the model proposed in this $\mathrm{PhD}$ research.

\section{References}

Abu Bakar, A. H., Abdul Razak, A., Abdullah, S., \& Awang, A. (2010). Project management success factors for sustainable housing: a framework. Asian Journal of Management Research, ISSN: 2229-3795, 66-80. [Online] Available: http://ipublishing.co.in/ajmrvol1no1/EIJMRS1007.pdf

Al-Tmeemy, S., Abdul-Rahman, H., \& Harun, Z. (2011). Future criteria for success of building projects in Malaysia. International Journal of Project Management, 29, 337-348. http://dx.doi.org/10.1016/j.ijproman.2010.03.003 
Anderson, E. S., Birchall, D., Jessen, S. A., \& Money, A. H. (2006). Exploring project success. Baltic Journal of Management, 1(2), 127-147. http://dx.doi.org/10.1108/17465260610663854

Atkinson, R. (1999). Project management: cost, time and quality, two best guesses and a phenomenon, its time to accept other success criteria. International Journal of Project Management, 17, 337-342. http://dx.doi.org/10.1016/S0263-7863(98)00069-6

Baccarini, D. (1999). The logical framework method for defining project success. Project Management Journal, 30(4), 25-32. [Online] Available: http://marketplace.pmi.org/Pages/ProductDetail.aspx?GMProduct=00100197200\&iss=1

Baker, B. N., Murphy, D. C., \& Fisher, D. (1988). Factor affecting success. In: Cleland, D. L. \& King, W. R. (Eds), Project Management Handbook (pp.902-909). New York: Van Nostrand Reinhold.

Belassi, W., \& Tukel O. L. (1996). A new framework for determining critical success/failure factors in projects. International Journal of Project Management, 14(3), 141-151. http://dx.doi.org/10.1016/0263-7863(95)00064-X

Betts, M., \& Lansley, P. (1995). International journal of project management: a review of the first ten years. International Journal of Project Management, 13(4), 207-217. http://dx.doi.org/10.1016/0263-7863(95)00001-7

Blindenbach-Driessen, F. (2006). Innovation management in project-based firms. Unpublished Doctoral dissertation, Erasmus University, Rotterdam.

Bryde, D. J., \& Robinson, L. (2005). Client versus contractor perspectives on project success criteria. International Journal of Project Management, 23, 622-629. http://dx.doi.org/10.1016/j.ijproman.2005.05.003

Bryde, D.J. (2008). Perceptions of the impact of project sponsorship practices on project success. International Journal of Project Management, 26 (8), 800-809. http://dx.doi.org/10.1016/j.ijproman.2007.12.001

Chan, A. P. C., \& Chan, A. P. L. (2004). Key performance indicators for measuring construction success. Benchmarking: An International Journal, 11(2), 203-221. http://dx.doi.org/10.1108/14635770410532624

Chan, A. P. C., Scott, D., \& Lam, E. W. M. (2002). Framework of success criteria for design/build projects. $\begin{array}{lllll}\text { Journal of } \text { Management in } & \text { Engineering, } & 18(3), & 120-128 .\end{array}$ http://dx.doi.org/10.1061/(ASCE)0742-597X(2002)18:3(120)

Chileshe, N., \& Haupt, T. C. (2005). Modelling critical success factors of construction project management (CPM). Journal of Engineering, Design, and Technology, 3(2), 140-154. http://dx.doi.org/10.1108/17260530510815376

Chua, D. K. H., Kog, Y. C., \& Loh, P. L. (1999). Critical success factors for different project objectives. Journal of Construction Engineering and Management, $125(3), \quad$ 142-150. http://dx.doi.org/10.1016/j.ijproman.2010.09.001

Cleland, D. I., \& King, W. R. (1983). Systems analysis and project management. New York: Mc Graw Hill.

Cooke-Davies, T. (2002). The 'real' success factor on projects. International Journal of Project Management, 17(3), 139-145. http://dx.doi.org/10.1016/S0263-7863(01)00067-9

Crawford, L., \& Pollack, J. (2004). Hard and soft projects: a framework for analysis. International Journal of Project Management, 22, 645-653. http://dx.doi.org/10.1016/j.ijproman.2004.04.004

Crawford, L., Pollack, J., \& England, D. (2006). Uncovering the trends in project management: journal emphases over the last 10 years. International Journal of Project Management, 24, 175-184. http://dx.doi.org/10.1016/j.ijproman.2005.10.005

De Wit, A. (1988). Measurement of project success. International Journal of Project Management, 6(3), 164-170. http://dx.doi.org/10.1016/0263-7863(88)90043-9

Diallo, A., \& Thuillier, D. (2004). The success dimensions of international development projects: the perceptions of African project coordinators. International Journal of Project Management, 22, 19-31. http://dx.doi.org/10.1016/S0263-7863(03)00008-5

Do, B. K., \& Tun, L. M. (2008). Success criteria and factors for international development projects: a life-cycle-based framework. Project Management Journal, 39, 72-84. http://dx.doi.org/10.1002/pmj.20034

Ellatar, S. M. S. (2009). Towards developing an improved methodology for evaluating performance and achieving success in construction projects. Scientific Research and Essay, 4, 549-554.

Evaristo, R., \& van Fenema P. C. (1999). A typology of project management: emergence and evolution of new 
forms. International Journal of Project Management, 17(5), 275-281. http://dx.doi.org/10.1016/S0263-7863(98)00041-6

Freeman, M., \& Beale, P. (1992). Measuring project success. Project Management Journal, 23, 8-17. [Online] Available: http://marketplace.pmi.org/Pages/ProductDetail.aspx?GMProduct $=00100690000 \&$ iss $=1$

Frodell, M. (2008). Swedish construction clients' views on project success and measuring performance. Journal of Engineering, Design, and Technology, 6, 21-32. http://dx.doi.org/10.1108/17260530810863316

Gidado, K. L. (1996). Project complexity, the focal point of construction project planning. Construction Management and Economics, 14(3), 213-225. http://dx.doi.org/10.1080/014461996373476

Hatush, Z., \& Skitmore, M. (1997). Evaluation contractor prequalification data: selection criteria and project success factors. Construction Management and Economics, 15(2), 129-147. http://dx.doi.org/10.1080/01446199700000002

HSE. (2001). Improving health and safety in construction: Phase 1: data collection, review and structuring. Health and Safety Executive (HSE) Books: Contract Research Report 387. Sudbury, Suffolk.

Hyvari, I. (2006). Success of projects in different organisational conditions. Project Management Journal, 37(4), $31-41$. [Online] Available: http://marketplace.pmi.org/Pages/ProductDetail.aspx?GMProduct=00100956600\&iss=1

Ika, L. A. (2009). Project success as a topic in project management journals. Project Management Journal, 40(4), 6-19. http://dx.doi.org/10.1002/pmj.20137

Jing, Y., Shen, Q. P., Drew, S. D., \& Ho, M. F. (2010). Critical success factors for stakeholder management: construction practitioners' perspectives. Journal of Construction Engineering and Management, 136(7), 778-786. http://dx.doi.org/10.1061/(ASCE)CO.1943-7862.0000180

King, I. (1996). The road to continuous improvement: BPR and Project Management. IIE solutions.

Lim, C. S., \& Mohammad, M. Z. (1999). Criteria of project success: an exploratory re-examination. $\begin{array}{lllll}\text { International Journal of Project } & \text { Management, } & \text { 17(4), } & \text { 243-248. }\end{array}$ http://dx.doi.org/10.1016/S0263-7863(98)00040-4

Liu, A. M. M. (1999). A research model of project complexity and goal commitment effects on project outcome. Engineering, Construction and Architectural Management, 6(2), 105-111. http://dx.doi.org/doi:10.1108/eb021103

Lock, D. (1984). Project management. New York: St Martins press.

Lu, W. S., \& Yuan, H. P. (2010). Exploring critical success factors for waste management in construction projects of China. Resources, Conservation and Recycling, 55(2), 201-208. http://dx.doi.org/doi:10.1016/j.resconrec.2010.09.010

Martin, C. C. (1976). Project management. New York: Amaco.

McCabe, S. (2001). Benchmarking in construction. UK: Blackwell Science.

Morris, P. W. G., \& Hough, G. H. (1987). The anatomy of major projects. New York: John Wiley and sons.

Munns, A. K., \& Bjeirmi, B. F. (1996). The role of project management in achieving project success. International Journal of Project Management, 14, 81-87. http://dx.doi.org/10.1016/0263-7863(95)00057-7

Navarre, C., \& Schaan, J. L. (1990). Design of project management systems from top management's perspective. Project Management Journal, 21(2), 19-27. [Online] Available: http://marketplace.pmi.org/Pages/ProductDetail.aspx?GMProduct=00100884800\&iss=1

Ng, S. T., Wong, Y. M. W., \&Wong, J. M. W. (2010). A structural equation model of feasibility evaluation and project success for public-private partnerships in Hong Kong. IEEE Transactions on Engineering Management, 57(2), 310-322.

Nguyen, L. D., Ogunlana, S. O., \& Lan, D. T. X. (2004). A study on project success factors in large construction projects in Vietnam. Engineering, Construction and Architectural Management, 11(6), 404-413. http://dx.doi.org/10.1108/09699980410570166

Pinto, J. K., \& Slevin, D. P. (1988). Critical success factors across the project life cycle. Project Management Journal, 19(3), 67-74. [Online] Available: http://marketplace.pmi.org/Pages/ProductDetail.aspx?GMProduct=00100880500\&iss=1 
Pinto, J. K., \& Slevin, D. P. (1989). Critical success factors in R\&D projects. Research Technology Management, 32, 31-35.

Pryke, S., \& Smyth, H. (2006). The management of complex projects: a relationship approach. UK: Blackwell Publishing, (Chapter 4).

Rockart, J. F. (1982). The changing role of the information system executive: a critical success factor perspective. MIT Sloan Management Review, 23(3), 3-13.

Rubin, I. M., \& Seeling, W. (1976). Experience as a factor in the selection and performance of project managers. IEEE Transaction on Engineering Management, 14(3), 131-135.

Sadeh, A., Dvir, D., \& Shenhar, A. (2000). The role of content type in the success of R\&D defence projects under increasing uncertainty. Project Management Journal, 31(3), 14-21. [Online] Available: http://marketplace.pmi.org/Pages/ProductDetail.aspx?GMProduct=00100195300\&iss=1

Sanvido, V. Grobler, F., Parfitt, K., Guvenis, M., \& Coyle, M. (1992). Critical success factors for construction projects. Journal of Construction Engineering and Management, 118(1), 94-111.

Shen, Q. P., \& Liu, G. W. (2003). Critical success factors for value management studies in construction. Journal of Construction Engineering and Management, $129(5), \quad 485-491$. http://dx.doi.org/10.1061/(ASCE)0733-9364(2003)129:5(485)

Shenhar, A. J., Dvir, D., Levy, O., \& Maltz, A. C. (2001). Project success: a multidimensional strategic concept. International Journal of Project Management, 34(6), 699-725. http//dx.doi.org/10.1016/S0024-6301(01)00097-8

Shenhar, A., \& Renier, J. (1996). How to define management? - a modular approach. Management Development Review, 9, 25-31. http:dx.doi.org/10.1108/09622519610181748

Shenhar, A., Levy, O., \& Dvir, D. (1997). Mapping the dimensions of project success. Project Management Journal, 28(2), 5-13. [Online] Available: http://marketplace.pmi.org/Pages/ProductDetail.aspx?GMProduct=00100250300\&iss=1

Stuckenbruck, L. C. (1986). Who determines project success? Paper presented at Proceeding of the Project Management Institute. Montreal, Canada, pp. 85-93.

Tiong, R. L. K., Yeo, K. T., \& McCarthy, S. C. (1992). Critical success factors in winning BOT contracts. Journal of Construction Engineering and Management, 118(2), 217-228. http://dx.doi.org/10.1061/(ASCE)0733-9364(1992)118:2(217)

Toor, S., \& Ogunlana, S. O. (2008). Critical COMs of success in large-scale construction projects: evidence from Thailand construction industry. International Journal of Project Management, 26, 420-430. http://dx.doi.org/10.1016/j.ijproman.2007.08.003

Turner, J. R. (1999). Editorial: Project management: a profession based on knowledge or faith. International Journal of Project Management, 17, 329-330.

Verma, V. K. (1995). Organizing projects for success. Project Management Institute. Newtown Square, PA.

Verma, V. K. (1996). Human resource skills for the project manager. Project Management Institute. Newtown Square, PA.

Wateridge, J. (1995). IT projects: a basis for success. International Journal of Project Management, 13, 169-172. http://dx.doi.org/10.1016/0263-7863(95)00020-Q

Westerveld, E. (2003). The project excellence model: linking success criteria and critical success factors. International Journal of Project Management, 21, 411-418. http://dx.doi.org/10.1016/S0263-7863(02)00112-6 
Table 1. Context-specific critical success factors

\begin{tabular}{|c|c|c|c|c|c|}
\hline Authors & $\begin{array}{l}\text { Abu Bakar, } \\
\text { Abdul Razak, } \\
\text { Abdullah \& } \\
\text { Awang, } 2010\end{array}$ & Bryde, 2008 & $\begin{array}{l}\text { Jing, Shen, Drew } \\
\text { \& Ho, } 2010\end{array}$ & $\begin{array}{l}\text { Lu \& Yuan, } \\
2010\end{array}$ & $\begin{array}{l}\text { Shen \& Liu, } \\
2003\end{array}$ \\
\hline \multirow[t]{11}{*}{ CSFs } & $\begin{array}{l}\text { Ensure } \\
\text { cost-efficient }\end{array}$ & $\begin{array}{l}\text { Define business } \\
\text { benefits/requirements }\end{array}$ & $\begin{array}{l}\text { Manage social } \\
\text { responsibilities }\end{array}$ & $\begin{array}{l}\text { Formulate } \\
\text { regulations }\end{array}$ & $\begin{array}{l}\text { Client's } \\
\text { support \& } \\
\text { active } \\
\text { participation }\end{array}$ \\
\hline & $\begin{array}{l}\text { Ensure } \\
\text { resource-efficient }\end{array}$ & $\begin{array}{l}\text { Establish project } \\
\text { strategy }\end{array}$ & $\begin{array}{l}\text { Formulate clear } \\
\text { project missions }\end{array}$ & $\begin{array}{l}\text { Identify good } \\
\text { system }\end{array}$ & Clear objective \\
\hline & $\begin{array}{l}\text { Ensure } \\
\text { competitive } \\
\text { design }\end{array}$ & $\begin{array}{l}\text { Monitor project } \\
\text { benefit }\end{array}$ & $\begin{array}{l}\text { Identify } \\
\text { stakeholder }\end{array}$ & $\begin{array}{l}\text { Promote } \\
\text { awareness }\end{array}$ & $\begin{array}{l}\text { Strong project } \\
\text { team }\end{array}$ \\
\hline & & $\begin{array}{l}\text { Agree project } \\
\text { definition }\end{array}$ & $\begin{array}{l}\text { Understand area } \\
\text { of interest }\end{array}$ & $\begin{array}{l}\text { Promote } \\
\text { effective } \\
\text { technologies }\end{array}$ & $\begin{array}{l}\text { Facilitator's } \\
\text { competency }\end{array}$ \\
\hline & & $\begin{array}{l}\text { General management } \\
\text { support (training and } \\
\text { environment) }\end{array}$ & $\begin{array}{l}\text { Explore project } \\
\text { needs and } \\
\text { constraints }\end{array}$ & $\begin{array}{l}\text { Avoid frequent } \\
\text { changes }\end{array}$ & $\begin{array}{l}\text { Control } \\
\text { workshop }\end{array}$ \\
\hline & & $\begin{array}{l}\text { Monitor projects' } \\
\text { business } \\
\text { environment }\end{array}$ & $\begin{array}{l}\text { Assess } \\
\text { stakeholders' } \\
\text { behaviors }\end{array}$ & $\begin{array}{l}\text { Continue } \\
\text { research \& } \\
\text { development }\end{array}$ & $\begin{array}{l}\text { Prepare and } \\
\text { understand } \\
\text { related } \\
\text { information }\end{array}$ \\
\hline & & $\begin{array}{l}\text { Cancel project if } \\
\text { appropriate }\end{array}$ & $\begin{array}{l}\text { Predict the } \\
\text { influence }\end{array}$ & $\begin{array}{l}\text { Conduct } \\
\text { vocational } \\
\text { training }\end{array}$ & $\begin{array}{l}\text { Plan for } \\
\text { implementation }\end{array}$ \\
\hline & & & Assess attributes & & $\begin{array}{l}\text { Analyse } \\
\text { function }\end{array}$ \\
\hline & & & Analyse conflicts & & Study timing \\
\hline & & & $\begin{array}{l}\text { Keep and } \\
\text { promote good } \\
\text { relationships }\end{array}$ & & $\begin{array}{l}\text { Interact among } \\
\text { participants }\end{array}$ \\
\hline & & & $\begin{array}{l}\text { Formulate proper } \\
\text { strategies }\end{array}$ & & $\begin{array}{l}\text { Cooperate } \\
\text { among } \\
\text { departments }\end{array}$ \\
\hline
\end{tabular}


Table 2. List of project lifecycle based critical success factors (Do \& Tun, 2008)

\begin{tabular}{|l|l|}
\hline Project lifecycle (stages) & \multicolumn{1}{c|}{ Division of success criteria } \\
\hline Conceptualising & $\begin{array}{l}\text { Clear target group needs } \\
\text { Agency capability } \\
\text { Stakeholder's interest }\end{array}$ \\
\hline Planning & $\begin{array}{l}\text { Gain key stakeholders support } \\
\text { Prepare for resource } \\
\text { Get ready for project start }\end{array}$ \\
\hline Implementing & $\begin{array}{l}\text { Plan the project } \\
\text { Keep inform key stakeholders about the process }\end{array}$ \\
\hline Closing & $\begin{array}{l}\text { Check the scope of work done } \\
\text { Report the results to key stakeholders }\end{array}$ \\
\hline Overall project success & $\begin{array}{l}\text { Good reputation } \\
\text { Good for beneficiaries } \\
\text { Good chance }\end{array}$ \\
\hline
\end{tabular}

Table 3. List of critical success factors across various success category (Shenhar \& Renier, 1996)

\begin{tabular}{|l|l|}
\hline \multicolumn{1}{|c|}{ Success category } & \multicolumn{1}{c|}{ Measurable success criteria } \\
\hline $\begin{array}{l}\text { Internal Project objectives } \\
\text { (Pre-completion) }\end{array}$ & $\begin{array}{l}\text { Meeting schedule } \\
\text { Within budget } \\
\text { Other resource constraints met }\end{array}$ \\
\hline $\begin{array}{l}\text { Benefits to customer } \\
\text { (Short term) }\end{array}$ & Meeting functional performance \\
& Meeting technical specification \& Standards \\
& Favorable impact on customer, customer's gain \\
& Fulfilling customer's needs \\
& Solving a customer's problem \\
& Customer is using product \\
& Customer expresses satisfaction \\
\hline Direct contribution & Immediate business and/or commercial success \\
(Medium term) & Immediate revenue and profits enhanced \\
& Larger market share generated \\
\hline Future opportunity & Will create new opportunities for future \\
(Long Term) & Will position customer competitively \\
& Will create new market \\
& Will assist in developing new technology \\
& Has, or will, add capabilities and competencies \\
\hline
\end{tabular}

Table 4. Macro-dimensions and micro-dimension of projects (Diallo \& Thuillier, 2004)

\begin{tabular}{|l|l|}
\hline \multicolumn{1}{|c|}{ Macro-dimensions } & \multicolumn{1}{c|}{ Micro-dimensions } \\
\hline Management success & $\begin{array}{l}\text { The project operated within budget } \\
\text { The project operated in time } \\
\text { The initial identified objectives were attained }\end{array}$ \\
\hline Project itself & $\begin{array}{l}\text { The project built institution capacity within the country } \\
\text { The project had a visible impact on the beneficiaries } \\
\text { The beneficiaries are satisfied by the goods or services } \\
\text { generated }\end{array}$ \\
\hline Profile & The project achieved a high national profile \\
\hline
\end{tabular}


Table 5. Cross selection of the project success notions

\begin{tabular}{|l|l|l|}
\hline \multicolumn{1}{|c|}{ Project success factors } & \multicolumn{1}{|c|}{ Project success criteria } & \multicolumn{1}{c|}{$\begin{array}{c}\text { Relationship between } \\
\text { project success factors and } \\
\text { criteria }\end{array}$} \\
\hline $\begin{array}{l}\text { Abu Bakar, Abdul Razak \& } \\
\text { Abdullah \& Awang, 2010 }\end{array}$ & $\begin{array}{l}\text { Al-Tmeemy, Abdul-Rahman } \\
\text { \& Harun, 2011 }\end{array}$ & $\begin{array}{l}\text { Anderson, Birchall, Jessen \& } \\
\text { Money, 2006 }\end{array}$ \\
\hline Belassi \& Tukel, 1996 & Atkinson, 1999 & Ng, Wong \& Wong, 2010 \\
\hline Bryde, 2008 & Baccarini, 1999 & Westerveld, 2003 \\
\hline Chua, Kog \& Loh, 1999 & Belassi \& Tukel, 1996 & \\
\hline Chileshe \& Haupt, 2005 & Blindenbach-Driessen, 2006 & \\
\hline Cleland \& King, 1983 & Bryde \& Robinson, 2005 & \\
\hline De Wit, 1988 & Chan \& Chan, 2004 & \\
\hline Gidado, 1996 & Chan, Scott \& Lam, 2002 & \\
\hline Hyvari, 2006 & Crawford \& Pollack, 2004 & \\
\hline Jing, Shen, Drew \& Ho, 2010 & Diallo \& Thuillier, 2004 & \\
\hline King, 1996 & Do \& Tun, 2008 & \\
\hline Lock, 1984 & Ellatar, 2009 & \\
\hline Liu, 1999 & Frodell, 2008 & \\
\hline Lu \& Yuan, 2010 & Hatush \& Skitmore, 1997 & \\
\hline Martin, 1976 & Lim and Mohammad, 1999 & \\
\hline Morris \& Hough, 1987 & Munns \& Bjeirmi, 1996 & \\
\hline Nguyen, Ogunlana \& Lan, 2004 & Navarre \& Schaan, 1990 & \\
\hline Pinto \& Slevin, 1989 & Sadeh, Dvir \& Shenhar, 2000 & \\
\hline Sanvido, Grobler, Parfitt, Guvenis \\
\& Coyle, 1992 & Shenhar, Dvir, Levy \& Maltz, & \\
\hline Shen \& Liu, 2003 & 2001 & \\
\hline Tiong, Yeo \& McCarthy, 1992 & Shenhar \& Renier, 1996 & \\
\hline Toor \& Ogunlana, 2008 & Stuckenbruck, 1986 & \\
\hline Verma, 1995 \& 1996 & & \\
\hline & & \\
\hline
\end{tabular}




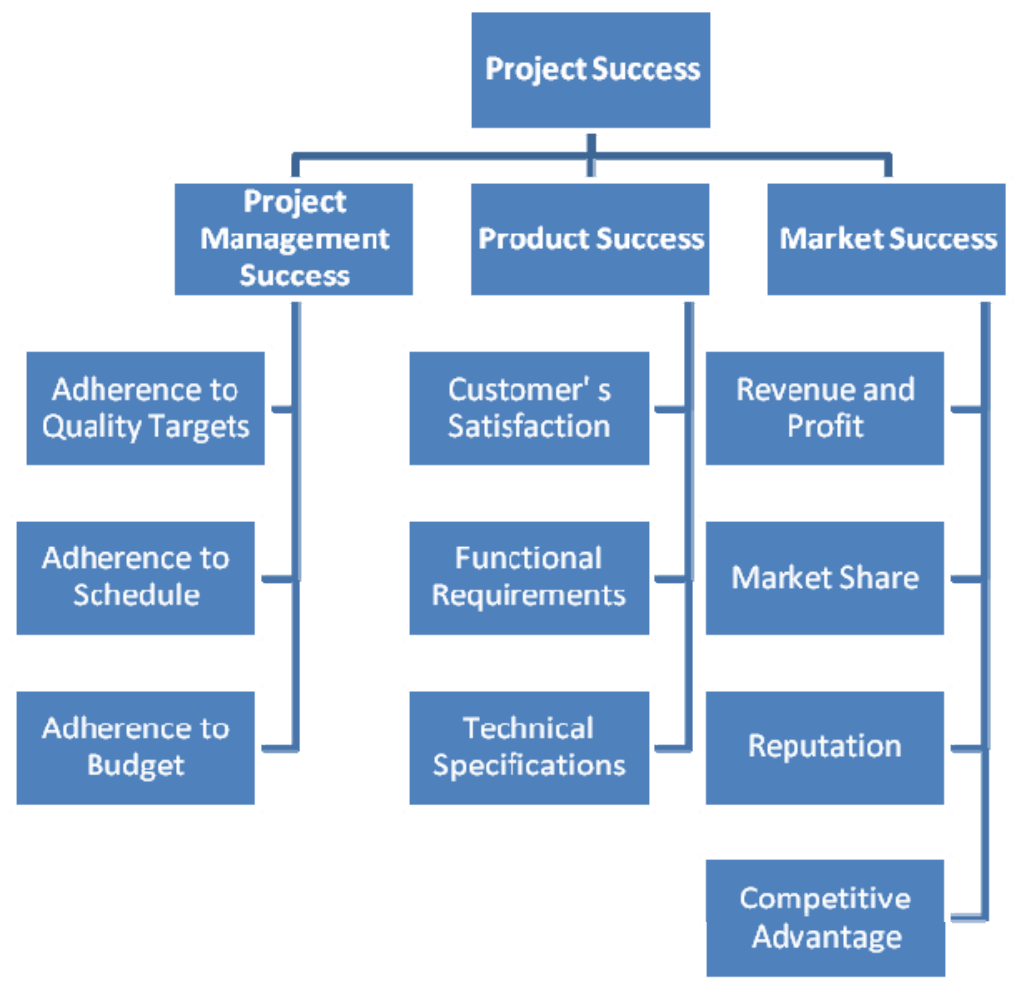

Figure 1. Success criteria for building projects (Al-Tmeemy, Abdul-Rahman \& Harun, 2011)

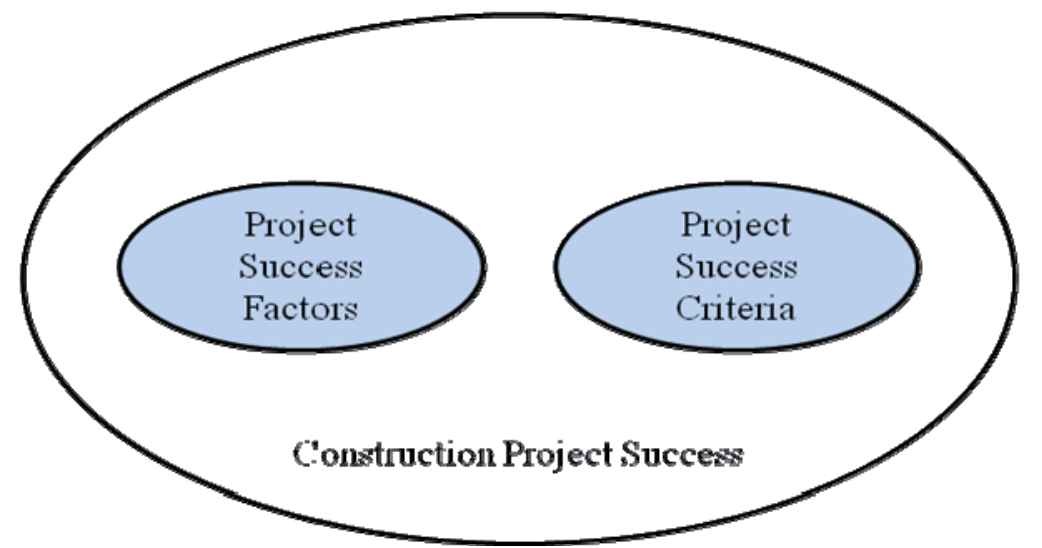

Figure 2. Conceptual framework for construction project success



Figure 3. Modified conceptual framework for construction project success 